DOI: $10.5800 /$ GT-2021-12-1-0512

\title{
STRUCTURE OF THE GOLETS VYSOCHAISHY GOLD DEPOSIT (NORTHERN TRANSBAIKALIA)
}

\author{
V.A. Vanin ${ }^{\otimes}$, A.M. Mazukabzov 이
}

Institute of the Earth's Crust, Siberian Branch of the Russian Academy of Sciences, 128 Lermontov St, Irkutsk 664033, Russia

ABSTRACT. The article describes the fold-thrust structure of the Golets Vysochaishy deposit located at the BaikalPatom Upland in the Marakan-Tunguska megasyncline. The latter is composed of terrigenous-carbonate carbonaceous rocks metamorphosed in greenschist facies conditions. The deposit is detected in the hanging wing of the asymmetric Kamenskaya anticline. In a cross section, the anticline is an S-shaped structure extending in the latitudinal direction. The main feature of the Golets Vysochaishy deposit is the development of interlayer sulfidization zones (pyrite, pyrrhotite), including gold-bearing ones. Its gold-ore zones tend to occur in layered areas of interlayer sliding in the rocks of the Khomolkhinskaya suite.

Four structural markers revealed within the deposit area are indicative of repeated deformation processes: (1) sublatitudinal folding, cleavage of the axial surface and its subsequent transformation into schistosity; (2) crenulation cleavage; (3) interlayer sliding and rock breakdown with interlayer drag folds, parallel microfractures and polished slickensides;

(4) large quartz veins and veinlets that cross cut the main structural elements in plan.

KEYWORDS: gold deposit; Baikal-Patom belt; Golets Vysochaishy; structural position; layering; cleavage of the axial surface; schistosity; crenulation cleavage

FUNDING: The study was financially supported by the Russian Foundation for Basic Research and the Government of the Irkutsk Region (project 20-45-380025).

\section{RESEARCH ARTICLE}

Correspondence: Vadim A.Vanin, vanin_geo@mail.ru
Received: October 7, 2020

Revised: December 7, 2020

Accepted: December 10, 2020

FOR CITATION: Vanin V.A., Mazukabzov A.M., 2021. Structure of the Golets Vysochaishy gold deposit (Northern Transbaikalia). Geodynamics \& Tectonophysics 12 (1), 60-75. doi:10.5800/GT-2021-12-1-0512 


\title{
СТРУКТУРА ЗОЛОТОРУДНОГО МЕСТОРОЖДЕНИЯ ГОЛЕЦ ВЫСОЧАЙШИЙ (СЕВЕРНОЕ ЗАБАЙКАЛЬЕ)
}

\author{
В.А. Ванин, А.М. Мазукабзов
}

Институт земной коры СО РАН, 664033, Иркутск, ул. Лермонтова, 128, Россия

АННОТАЦИЯ. Приводится описание складчато-надвиговой структуры месторождения Голец Высочайший, расположенного на территории Байкало-Патомского нагорья в пределах Маракано-Тунгусской мегасинклинали. Последняя сложена терригенно-карбонатными углеродистыми породами, метаморфизованными в условиях зеленосланцевой фации. Месторождение локализовано в висячем крыле асимметричной Каменской антиклинали $\mathrm{S}$-образной формы в поперечном сечении, протягивающейся в широтном направлении. Главной особенностью месторождения Голец Высочайший является развитие межслоевых зон сульфидизации (пирит, пирротин), в том числе и золотоносных. Золоторудные тела тяготеют к послойным зонам межслоевого скольжения в породах Хомолхинской свиты.

В пределах месторождения установлены четыре структурных маркера, указывающих на неоднократность деформационных процессов: 1) формирование складчатости субширотной ориентировки, кливажа осевой поверхности и последующее его трансформирование в сланцеватость; 2) формирование кренуляционного кливажа; 3) межслоевые подвижки (срывы), сопровождающиеся межслоевыми складками волочения, параллельными микротрещинами, а также отполированными зеркалами скольжения; 4) формирование крупных кварцевых жил и прожилков, занимающих секущее положение по отношению к основным плоскостным структурным элементам.

КЛЮчЕВЫЕ СЛОВА: месторождение золота; Байкало-Патомский пояс; Голец Высочайший; структурная позиция; слоистость; кливаж осевой поверхности; сланцеватость; кренуляционный кливаж

ФИНАНСИРОВАНИЕ: Исследование выполнено при финансовой поддержке РФФИ и Правительства Иркутской области в рамках научного проекта № 20-45-380025.

\section{1. ВВЕДЕНИЕ}

Территория Северного Забайкалья характеризуется наличием многочисленных золоторудных объектов, различающихся по масштабам: от незначительных рудопроявлений до крупных и уникальных коренных месторождений золота, таких как Сухой Лог, Вернинское, Красное, Голец Высочайший, Чертово Корыто и др. Несмотря на длительное изучение этих месторождений, возникают вопросы, касающиеся структурной позиции и процессов их формирования [Distler et al., 1996; Buryak et al., 2002; Laverov et al., 2007; Large et al., 2007; Meffre et al., 2008; Yudovskaya et al., 2011, 2016; Tauson et al., 2009; Tarasova et al., 2016, 2020; и др.].

Ведущая роль в локализации золоторудных проявлений отводится структурным факторам в совокупности с определенными литолого-стратиграфическими разностями. Большинство исследователей придерживаются мнения о контроле рудной минерализации антиклинальными структурами с обязательным наличием разрывных нарушений в осевой части или в перевернутом крыле антиклинали (например [Buryak, Khmelevskaya, 1997; Large et al., 2007; Nemerov et al., 2010; Kucherenko et al., 2012; Kotov, 2013; Tarasova et al., 2020]). Тем не менее никто из исследователей наличие разломов и приуроченных к ним золоторудных зон не продемонстрировал. Парадокс разломов не обошел стороной и практически всесторонне изученное месторождениегигант Сухой Лог, главной проблемой которого остается слабоизученная структура. Часто приводятся данные о наличии или отсутствии зон рудоконтролирующих разломов. Например, при описании месторождения Сухой Лог в работах [Buryak, Khmelevskaya, 1997; Lobanov et al., 1976] широко распространенные зоны рассланцевания были приняты за разрывные структуры. В статье [Vood, Popov, 2006] четко говорится, что ни одного крупного разлома не известно внутри месторождения Сухой Лог. В работе [Yudovskaya et al., 2011] выдвигается гипотеза постскладчатого формирования рудной минерализации, что также подразумевает, но не доказывает наличие разрывных структур. Таким образом, тема наличия разломов на месторождении Сухой Лог не раскрыта.

Вопросы структуры месторождения Голец Высочайший затрагивались в работах [Sher, 1961; Buryak, 1966; Ivanov, 2014]. В работе [Ivanov, 2014] был сделан вывод о существовании на месторождении Голец Высочайший крупного пластического разлома, дислоцированного в антиклинальную складку. В работах [Sher, 1961; Buryak, 1966] обращалось внимание на наличие на месторождении Голец Высочайший и в Бодайбинском синклинории в целом межслоевых скольжений, что имеет немаловажное значение для обоснования процессов рудообразования. Проблема выделения разрывных нарушений «рудного» возраста в высокопластичных углеродистых породах Бодайбинского синклинория остро стоит и по сей день. 
Неоднозначность трактовки генезиса и структурной позиции этих объектов обусловлена тем, что Северное Забайкалье является одной из ключевых структур сложно построенного Центрально-Азиатского складчатого пояса (ЦАСП), претерпевшей многочисленные тектонотермальные перестройки, проявившиеся на широком возрастном интервале - от раннего палеозоя до кайнозоя.

Основной целью настоящей работы является расшифровка рудоконтролирующей структуры золоторудного месторождения Голец Высочайший, а также этапов его структурной эволюции.

\section{2. МЕТОДИКА ИССЛЕДОВАНИЯ}

Регион, в котором располагается месторождение, характеризуется сложным складчато-надвиговым строением, набором пород флишоидного типа, измененных в условиях зеленосланцевой фации метаморфизма, и слабой обнаженностью. Это создает определенные трудности при изучении структуры рудного поля и выяснении структурного контроля в распределении золота в пределах месторождений. Для подобных условий наиболее приемлемым оказывается сочетание общих методов геологического картирования с детальными структурными наблюдениями. Большое внимание уделялось изучению и анализу малых структурных элементов, размерность которых варьируется от визуально наблюдаемых в образцах до крупных структур, картируемых в пределах групп обнажений. Сюда входят складки с набором характеризующих их элементов, межзерновой и кренуляционный кливаж, элементы залегания слоистости и сланцеватости, будинаж, трещины разной морфологии и кинематики. Особое внимание уделялось кливажу, соотношение которого со слоистостью позволяет провести реконструкцию складчатых структур при пологих залеганиях толщи и их значительной эрозии. Малые структурные формы, составляющие структурные парагенезы, позволяют выяснить динамические и кинематические условия формирования структуры района. Петроструктурные исследования использовались при изучении рудоконцентрирующих микроструктурных форм и для восстановления стадийности рудогенеза. Значительное внимание было уделено выявлению признаков, отражающих реологию пород при деформации. Перечисленный комплекс методов является необходимым для реконструкции складчатой структуры месторождения, в строении которого участвуют гетерогенные по составу породы, обладающие разной компетентностью при деформации. При обработке плоскостных и линейных элементов применялись методы стереогеометрического анализа.

\section{3. РЕГИОНАЛЬНАЯ СТРУКТУРНО-ТЕКТОНИЧЕСКАЯ ПОЗИЦИЯ ХОМОЛХИНСКОГО РУДНОГО УЗЛА}

Месторождение Голец Высочайший входит в Хомолхинское рудное поле, которое является составной частью Бодайбинского рудного района, пространственно совпадающего со сложно построенным Бодайбинским синклинорием. Балансовые запасы месторождения оцениваются в 85.579 т золота [Babyak et al., 2019].

Территориально месторождение Голец Высочайший расположено по левому борту р. Хомолхо, в пределах Хомолхинского рудного узла, включающего также месторождение Угаханское (рис. 1). Рудный узел охватывает верховья рек Хомолхо, Угахан и Бол. Патом и заключен в общую структуру Байкало-Патомского нагорья (БПН) (Ленский район). В структурном плане месторождение располагается в пределах Маракано-Тунгусской мегасинклинали и тяготеет к висячему крылу асимметричной Каменской антиклинали третьего порядка.

Структура БПН в пределах территории от р. Хомолхо до р. Маракан представляет собой складчато-надвиговую зону (СН3) южной вергентности с субширотной ориентировкой шарниров региональных складок, слоистости $\left(\mathrm{S}_{0}\right)$ и кливажа осевой поверхности $(\mathrm{OП})\left(\mathrm{S}_{1}\right)$. Стоит отметить, что изученность данной СНЗ весьма слабая и представления о ней складываются по результатам, полученным при региональном изучении территории, вмещающей ряд золоторудных месторождений, среди которых Сухой Лог, Вернинское, Угаханское, Голец Высочайший, Невское и др. Непосредственно структуры самих месторождений дают лишь общие представления о геолого-структурном строении СНЗ. Согласно собственным наблюдениям и данным, опубликованным в работах [Ivanov, 2014; Vood, Popov, 2006; и др.], осевые поверхности складок в СНЗ запрокинуты на юг и юго-запад. Сами складки имеют флексурные, опрокинутые и лежачие формы (например, Каменская, Сухоложская и Вернинская антиклинали [Vood, Popov, 2006; Kucherenko et al., 2012; Ivanov, 2014]). По мере приближения к «краевому шву» Мамской кристаллической зоны и Бодайбинского блока, вблизи р. Маракан в результате наложения поперечных деформаций субширотная ориентировка структур меняет свое направление до северо-западной ориентировки шарниров и слоистости (рис. 1) [Vanin, Mazukabzov, 2020; Flaass, 1971]. В зоне наложения поперечной складчатости располагаются месторождения Ожерелье и Ыканское с северозападной ориентировкой золоторудных зон.

Месторождение Голец Высочайший локализовано в сохранившемся висячем крыле, в одном километре к северу от оси Каменской антиклинали в ее пологой периклинальной (вырождающейся) части (рис. 2). Последняя протягивается более чем на 13 км, имея ширину в среднем 1.5 км. Шарнир антиклинали частично эродирован и фиксируется в руч. Каменном (рис. 3, а, б), р. Хомолхо (рис. 3, г, д, ж, з) и на их водоразделе (рис. 3, в, е). Шарнир имеет изогнутую форму и ориентирован в запад-северо-западном направлении (см. рис. 2). Каменская антиклиналь характеризуется отчетливо асимметричным строением - северное крыло залегает значительно более полого $\left(10-20^{\circ}\right)$, чем южное. Падение южного крыла имеет резко выраженный крутой наклон на юг, достигая $80^{\circ}$. Далее на юг падение слоистости постепенно выполаживается вплоть до обратного 
падения, приобретая моноклинальное залегание под углом 10-20 с падением на север (см. рис. 2). На структурных диаграммах (рис. 4, диаграмма I, III и IV) полюсы слоистости образуют пояс субмеридионального простирания. Структурные элементы слоистости имеют различное залегание - от пологого (3-20) до крутого (до $80^{\circ}$ ). Такое положение структурных элементов указывает на флексурную форму складки, шарнир которой под небольшим углом $\left(10^{\circ}\right)$ погружается в юговосточном направлении. На рис. 4 помещены три поперечных разреза рудолокализующей антиклинали, ориентированных в северо-восточном направлении, построенных на основе замеров плоскостных структурных элементов слоистости и кливажа ОП. ОП Каменской антиклинали изогнута, аз. ее падения варьируется от 340 до $15^{\circ}$. Падение кливажа ОП в разных частях структуры варьируется от 20 до $45^{\circ}$ на север.
На западном фланге за пределами месторождения ОП имеет угол падения $40^{\circ}$ (рис. 4 , разрез АБ). В руч. Каменном отложения хомолхинской свиты, обладающие повышенными содержаниями золота [Budyak et al., 2016], размыты вплоть до слабозолотоносных отложений угаханской свиты. На востоке, в районе карьера месторождения Голец Высочайший (рис. 4, разрез ВГ), наклон осевой поверхности антиклинали меняется до $20^{\circ}$. Замок складки здесь в большей степени эродирован вплоть до ее ядерной части, где также вскрыты отложения угаханской свиты. Далее на восток, за пределами эксплуатационного карьера, в районе отработанной элювиально-делювиальной россыпи Каменская антиклиналь постепенно выполаживается, угол залегания слоистости на северном крыле составляет 10-15․ Шарнир складки в этой части разреза фиксируется по разнонаправленному залеганию пологой


Рис. 1. Структурная схема центральной части Байкало-Патомского нагорья (по [Flaass, 1971], с дополнениями). На врезке показано положение схемы в структуре Саяно-Байкало-Патомского складчатого пояса.

Fig. 1. Schematic structural map of the central part of the Baikal-Patom Upland (after [Flaass, 1971], with additional data). Its position relative to the structure of the Sayan-Baikal-Patom fold belt is shown in the inset. 


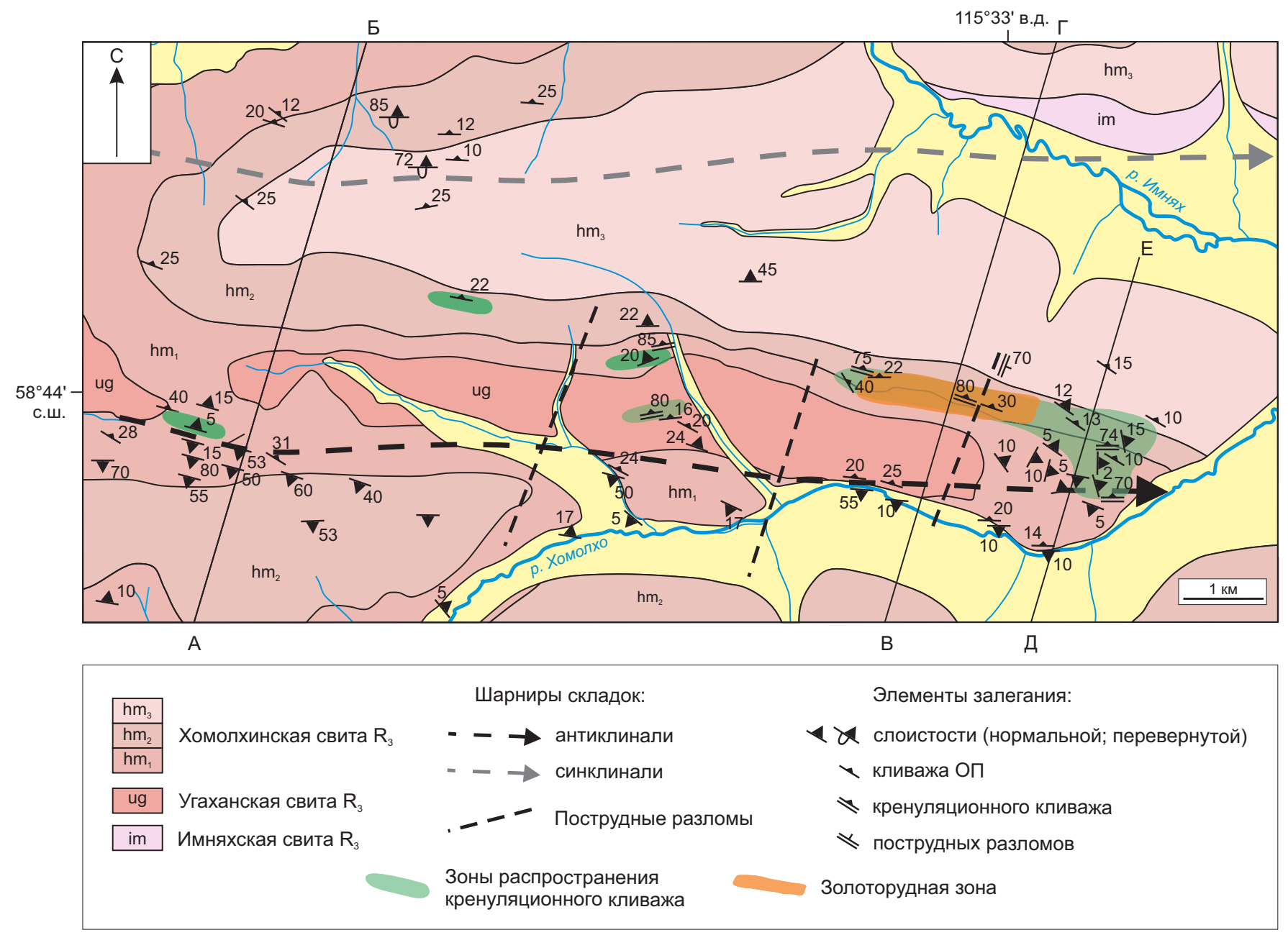

Рис. 2. Геолого-структурная схема месторождения Голец Высочайший (составлена по фондовым материалам (И.Н. Бирюкова) с дополнениями структурных элементов).

Fig. 2. Geological structure of the Golets Vysochaishy deposit. The scheme is based on archive materials provided by I.N. Biryukova; structural elements are added.

слоистости - 5-10, редко до $15-22^{\circ}$ (рис. 4, диаграмма IV). Южное крыло в этой части разреза не вскрыто и, вероятно, находится южнее горных выработок. Элементы залегания кливажа ОП имеют наклон $10-15^{\circ}$ на север. В этой части разреза фрагментарно сохранились отложения золотоносной нижней подсвиты хомолхинской свиты (рис. 4, разрез ДЕ).

В висячем крыле антиклинали наблюдались межслоевые асимметричные складки волочения (рис. 5, а), различные складки с остроугольными замками, изоклинальные и лежачие (рис. 5, б) складки. Для них характерны пологие углы залегания осевой плоскости. В шарнирной части замка Каменской антиклинали изоклинальные складки сменяются открытыми складками полуэллиптической морфологии с углами между крыльями $160^{\circ}$ (см. рис. 3, г, д). Судя по зеркалу складчатости, построенной по замкам открытых складок, фрагмент замка Каменской антиклинали имеет дугообразную форму, выпуклую к югу. Кливаж осевой поверхности в этих складках имеет более крутой угол падения (среднее значение $40^{\circ}$ ) в сравнении с висячим северным крылом. Иногда отмечается веерообразная морфология кливажа.

По серии разрезов, построенных поперек антиклинали, видно, что амплитуда Каменской антиклинали уменьшается в восточном направлении, что приводит к ее затуханию, т.е. она трансформируется в субгоризонтально лежащую плоскость. Анализируя наклон осевой поверхности по разрезам, можно увидеть, что она из пологолежащей постепенно приобретает наклон до $40^{\circ}$.

В свою очередь, Каменская рудолокализующая антиклиналь осложняет лежачее крыло крупной Имняхской синклинали, шарнир которой находится в 4 км к северу (см. рис. 2). Ось синклинали ориентирована в восточном направлении и достигает в длину 15 км. Ширина складки не менее 3 км. Висячее крыло синклинали в пределах рассматриваемой площади полностью эродировано. Замковая часть складки фиксируется в обнажении правого притока руч. Правый Имнях (рис. 6, а, б).

Здесь отчетливо наблюдаются плоскостные элементы слоистости и подходящие к ней под тупым углом 

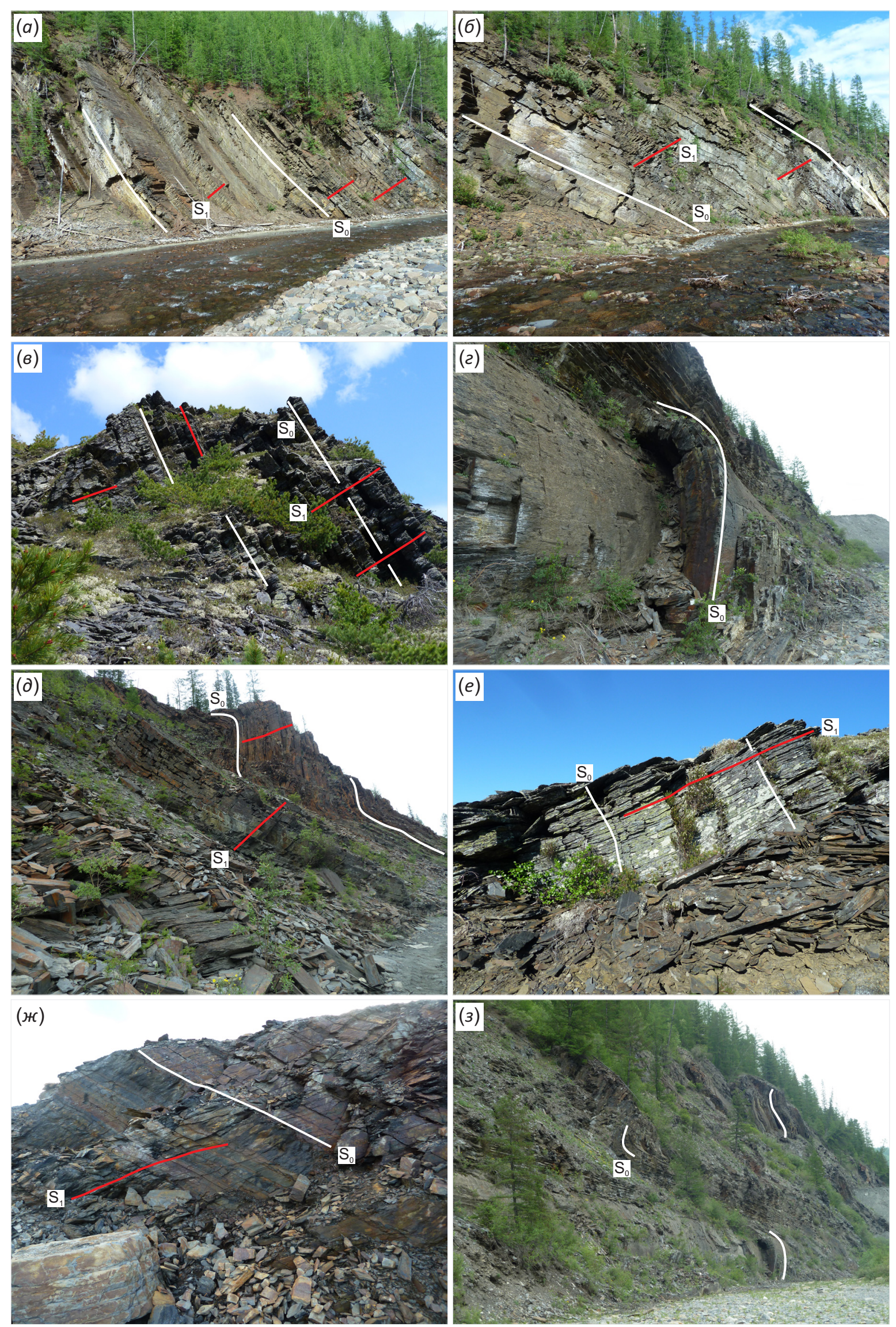

Рис. 3. Фрагменты замка Каменской антиклинали. Белой линией $\left(\mathrm{S}_{0}\right)$ показана слоистость, красной линией $\left(\mathrm{S}_{1}\right)-$ кливаж осевой поверхности.

Fig. 3. Fragments of the Kamenskaya anticline's hinge. White line $\left(\mathrm{S}_{0}\right)$ - layering; red line $\left(\mathrm{S}_{1}\right)$ - cleavage of the axial surface. 
плоскости кливажа ОП. Слоистость часто будинирована (рис. 6, б) и изогнута в микроскладки (рис. 6, в). На структурной диаграмме (см. рис. 4, диаграмма II) полюсы слоистости образуют пояс меридионального простирания. Плоскости слоистости характеризуются крутыми углами падения 55-85, а углы падения кливажа ОП варьируются от 12 до $35^{\circ}$. По взаимоотношению кливажа и слоистости в замке синклиналь имеет опрокинутую форму. Угол падения лежачего крыла варьируется в пределах $10-20^{\circ}$ (см. рис. 4). Осевая поверхность Имняхской синклинали имеет угол падения на север $10-20^{\circ}$, аз. падения варьируется от 355 до $5^{\circ}$. Замок синклинали выполнен породами верхней подсвиты хомолхинской свиты.

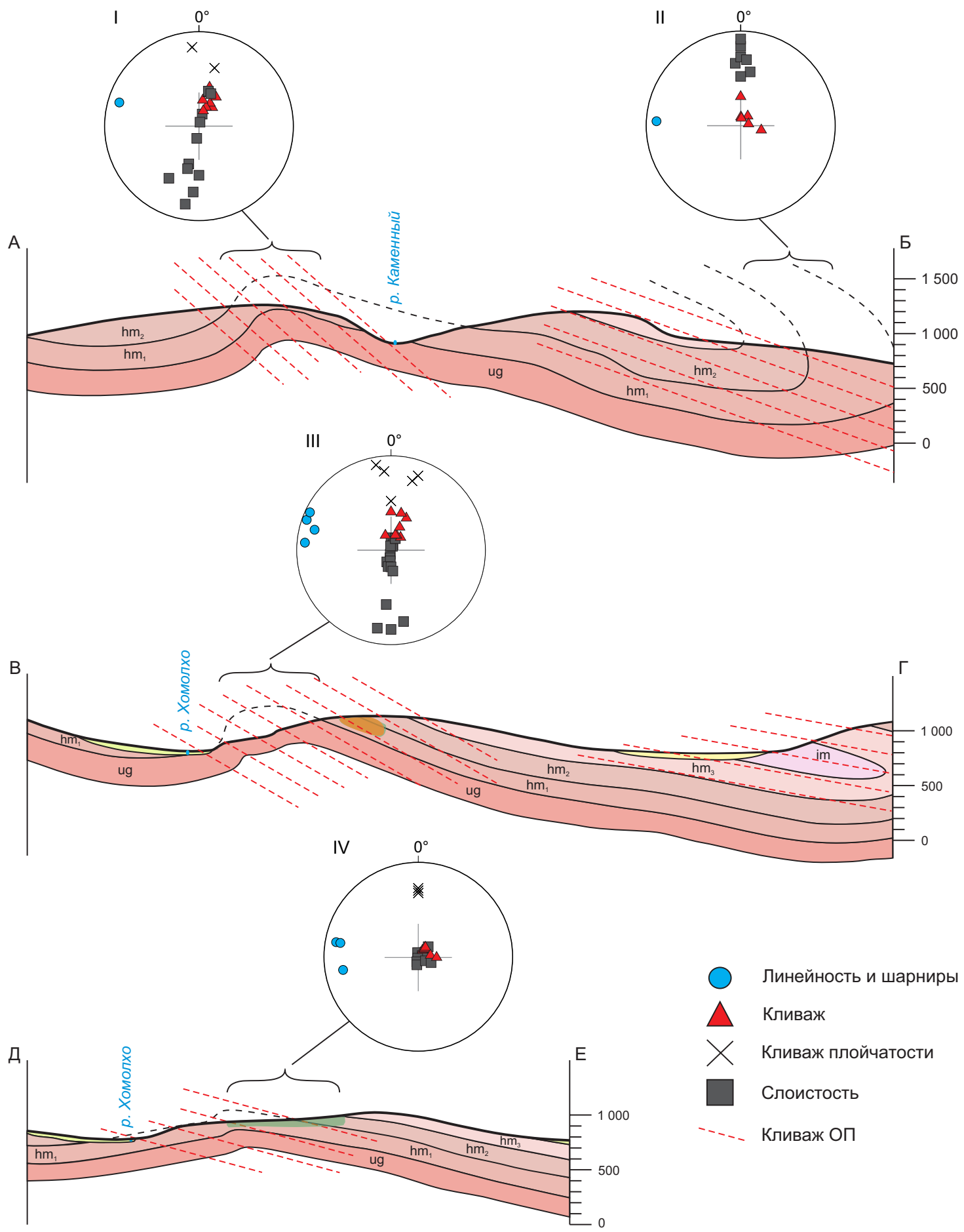

Рис. 4. Схематический разрез месторождения Голец Высочайший. Структурные диаграммы изображены в верхней полусфере, равноугольной проекции. Остальные условные обозначения см. на рис. 2. Пояснения в тексте.

Fig. 4. Schematic section of the Golets Vysochaishy deposit. Structural diagrams are shown in the upper hemisphere, conformal projection. See the legend to Fig. 2. Explanations in the text. 

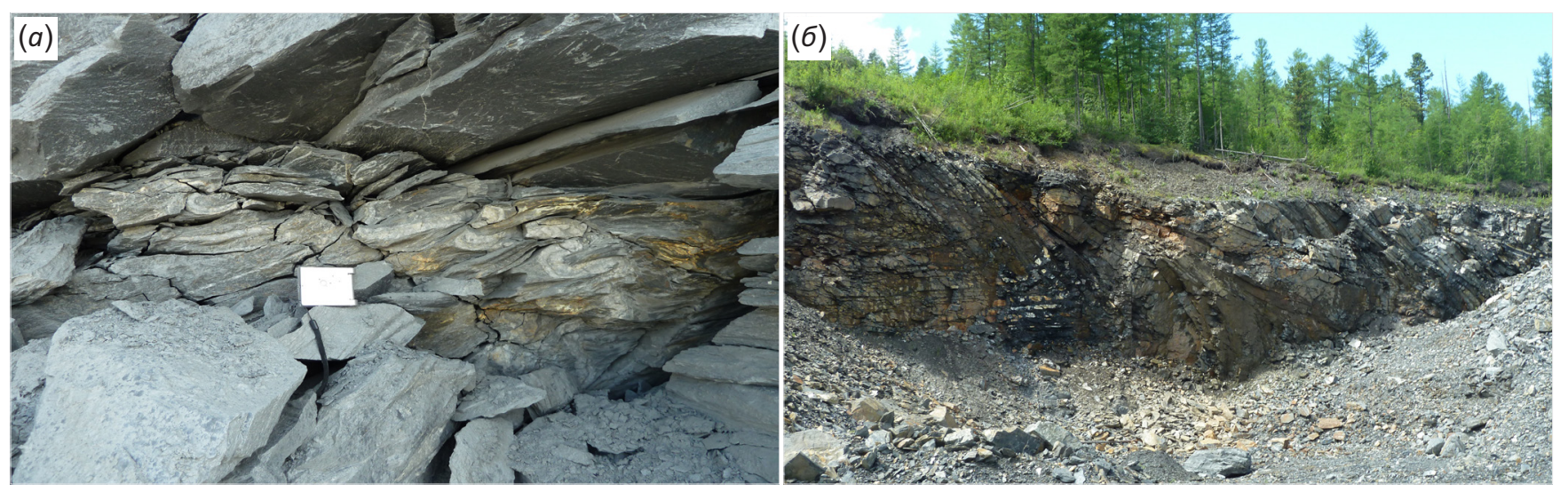

Рис. 5. Формы складок месторождения Голец Высочайший.

Fig. 5. Forms of folds of the Golets Vysochaishy deposit.
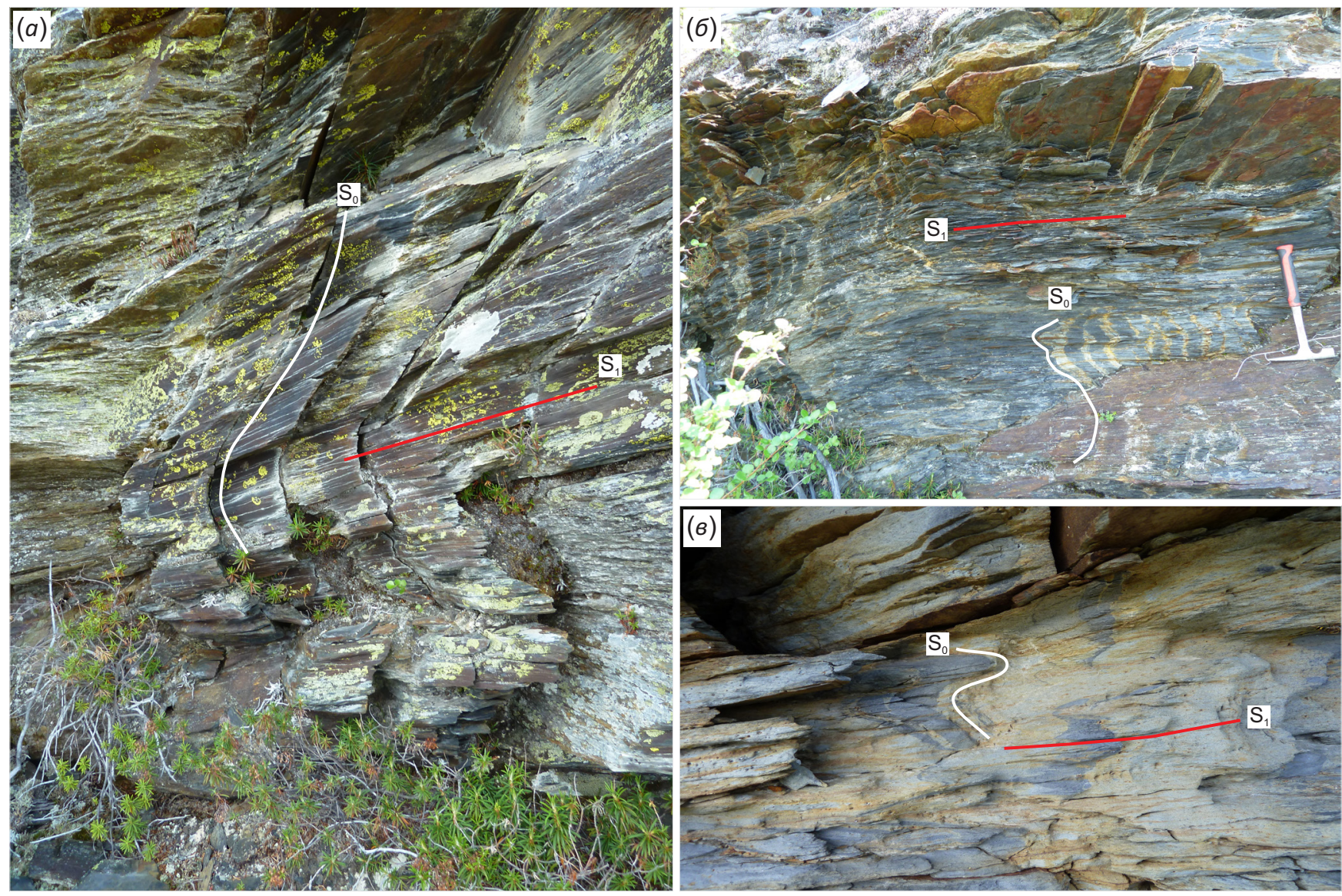

Рис. 6. Фрагменты замка Имняхской синклинали. $\mathrm{S}_{0}$ - слоистость, $\mathrm{S}_{1}$ - кливаж осевой поверхности.

Fig. 6. Fragments of the Imnyakh syncline's hinge. $\mathrm{S}_{0}$ - layering, $\mathrm{S}_{1}$ - cleavage of the axial surface.

\section{4. ГЕОЛОГО-СТРУКТУРНАЯ ХАРАКТЕРИСТИКА МЕСТОРОЖДЕНИЯ ГОЛЕЦ ВЫСОЧАЙШИЙ}

На месторождении Голец Высочайший вмещающие породы представлены высокопластичными терригенно-карбонатными отложениями хомолхинской свиты неопротерозойского возраста ( 610 млн лет), накопление которых проходило в условиях спрединга задугового бассейна [Chumakov et al., 2013; Powerman et al., 2015; Chugaev et al., 2017; Budyak et al., 2019].
Золоторудные зоны характеризуются длительным развитием и представлены послойными сульфидизированными углеродистыми сланцами, в составе которых преобладает серицит, кварц, карбонат при незначительном количестве хлорита. Видимая невооруженным глазом сульфидная минерализация (пирит и пирротин) имеет формы прожилков (ранняя стадия) и кубических форм пирита (более поздняя стадия), что совпадает с выделенной стадийностью минералообразования 
на месторождениях Сухой Лог, Красное, Вернинское, Чертово Корыто, Кавказ, Копыловское [Large et al., 2007; Meffre et al., 2008; Tarasova et al., 2016, 2020; Chugaev et al., 2014; Palenova et al., 2015; Yudovskaya et al., 2016]. Ранняя генерация образует прожилки с кварцем мощностью от 0.1-до 2.0 см. Поздняя представлена крупнокристаллическими кубическими зернами размером до 3 см. Пирротин в виде гнезд и прожилков ассоциирует с ранней генерацией пирита. Кроме пирита и пирротина отмечаются также халькопирит, галенит и сфалерит [Buryak, Khmelevskaya, 1997; Goryachev et al., 2019].

Помимо послойных золоторудных зон, на месторождении присутствуют кварцевые жилы (более 1 м) и прожилки. Жилы часто будинированы, имеют редкую вкрапленность кубического пирита. Кварц в жилах светло-серый. Жилы и прожилки широко распространены в пределах региона. На месторождении Голец Высочайший они занимают секущее положение по отношению к слоистости и кливажу ОП и имеют более поздний возраст по отношению к послойным. Несмотря на единичные находки самородного золота в кварцевых жилах месторождения Голец Высочайший, собственной экономической значимости они не имеют.

Главными плоскостными структурными элементами на месторождении являются слоистость $\left(\mathrm{S}_{0}\right)$, кливаж осевой поверхности (сланцеватость $\left(\mathrm{S}_{1}\right)$ ) и кренуляционный кливаж (кливаж плойчатости $\left(\mathrm{S}_{2}\right)$ ). Наиболее ранним из распознаваемых структурных элементов в породах рассматриваемой территории является слоистость $\mathrm{S}_{0}$ На крыльях складок этот плоскостной элемент распознается с большим трудом, что связано с наложением на него элементов кливажа ОП, ввиду чего он изучался в замках и призамковых частях складок либо в шлифах (рис. 7). Слоистость в замках складок интенсивно деформирована, растянута и будинирована (см. рис. 6). В замках Каменской антиклинали и Имняхской синклинали отмечаются микроскладки, осевые поверхности которых располагаются поперек межслоевых поверхностей (см. рис. 6; рис. 8). В шлифах часто отмечается секущее положение кливажа ОП $\left(\mathrm{S}_{1}\right)$ по отношению к слоистости $\left(\mathrm{S}_{0}\right)$ под углом $10-20^{\circ}$ (см. рис. 7).

На плоскостях слоистости в редких случаях встречаются отполированные до блеска зеркала скольжения. Межслоевые подвижки часто сопровождаются образованием микротрещин и микроразломов, параллельных плоскостным элементам слоистости (см. рис. 7).

Ярко выраженной особенностью месторождения Голец Высочайший является приуроченность сульфидной минерализации (пирит, пирротин), в том числе золотосодержащей, исключительно к плоскостям слоистости (рис. 9, а). Особо отчетливо это наблюдается в замках складок, где слоистость перпендикулярна кливажу ОП. В некоторых случаях слоистость практически не различима невооруженным глазом и распознается по трассирующей ее рудной минерализации (рис. 9, б).

В висячем крыле Каменской антиклинали в наиболее продуктивной части золоторудной зоны фиксируется будинаж послойных кварц-сульфидных и пирит-пирротиновых прожилков, которые до этого были дислоцированы с формированием флексурных микроскладок. Наблюдаемый здесь кубический пирит (по морфологии подобен пострудному пириту), согласно [Large et al., 2007; Meffre et al., 2008; Tauson et al., 2015; Tarasova et al., 2020], подвержен деформациям с образованием теней давления в результате ротации (рис. 10). Одновременно во вмещающих пирит сланцах в участках сжатия возник кренуляционный кливаж (рис. 10, врезка).

Кливаж ОП на территории месторождения является сквозным, пронизывает насквозь слоистость деформированных слоев (см. рис. 7) и почти соответствует наклону осевой поверхности Имняхской синклинали и Каменской антиклинали. На рис. 4, диаграммы I, II, III, IV, кливаж ОП имеет разные углы наклона в разных частях Каменской флексурной антиклинали. В западной и центральной части рудоконтролирующей антиклинали кливаж ОП имеет угол падения преимущественно 30-40, значения азимута падения образуют субмеридиональный разброс (см. рис. 4, диаграмма I, IV). Севернее, в Имняхской синклинали, значения кливажа ОП имеют более пологий угол падения, азимут падения имеет значения, сосредоточенные в центральной части полусферы (см. рис. 4, диаграмма II). В восточной части разреза Каменской флексуры кливаж ОП имеет более пологий угол наклона, чем в западной части разреза, и составляет преимущественно $10^{\circ}$, азимут падения варьируется от 15 до $90^{\circ}$ (см. рис. 4, разрез ДЕ, диаграмма IV). По плоскостям кливажа ОП установлена плоскопараллельная ориентировка слюдистых

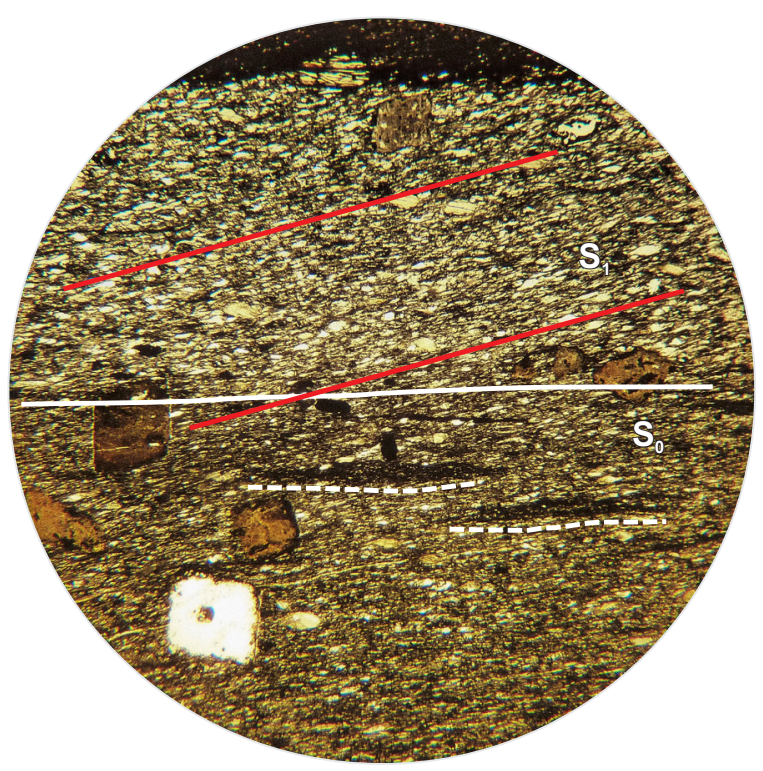

Рис. 7. Взаимоотношение плоскостных структурных элементов на месторождении Голец Высочайший. $\mathrm{S}_{0}$ - слоистость, $\mathrm{S}_{1}-$ кливаж осевой поверхности. Пунктирной линией показаны микротрещины.

Fig. 7. Relationships between plan structural elements at the Golets Vysochaishy deposit. $\mathrm{S}_{0}$ - layering, $\mathrm{S}_{1}$ - cleavage of the axial surface; dashed lines - microfractures. 
минералов, что свидетельствует о длительном продолжении деформационных процессов и фактически трансформировании кливажа ОП в сланцеватость (см. рис. 7).

В замках складок, осложняющих Каменскую антиклиналь, кливаж ОП иногда приобретает веерообразную форму (рис. 11).

Кренуляционный кливаж $\left(\mathrm{S}_{2}\right)$ на месторождении проявлен дискретно и в большей степени распространен в пределах золоторудных тел (рис. 12, а, б; рис. 13, a, б). Аз. падения кренуляционного кливажа варьируется от 355 до $20^{\circ}$ и имеет крутые углы падения (50$80^{\circ}$ ) (см. рис. 4, диаграмма I, III, IV). Характеризуется резкими и постепенными переходами от микролитонов к кливажной зоне (рис. 13, а, б).

\section{5. ОБСУЖДЕНИЕ РЕЗУЛЬТАТОВ}

На территории месторождения и за его пределами геолого-структурными наблюдениями выделены четыре структурных маркера, указывающих на неоднократность деформационных процессов.

1. При изучении кливажа ОП в шлифах установлена плоскопараллельная ориентировка слюдистых минералов по плоскостям кливажа ОП (см. рис. 7), что свидетельствует о длительном продолжении деформационных процессов и фактически трансформировании кливажа ОП в сланцеватость (см. ниже).

2. На ранее сформированные породы с ориентированной текстурой наложен кренуляционный кливаж (см. рис. 12; рис. 13). Последний всегда сопровождается микроскопической складчатостью, в которую

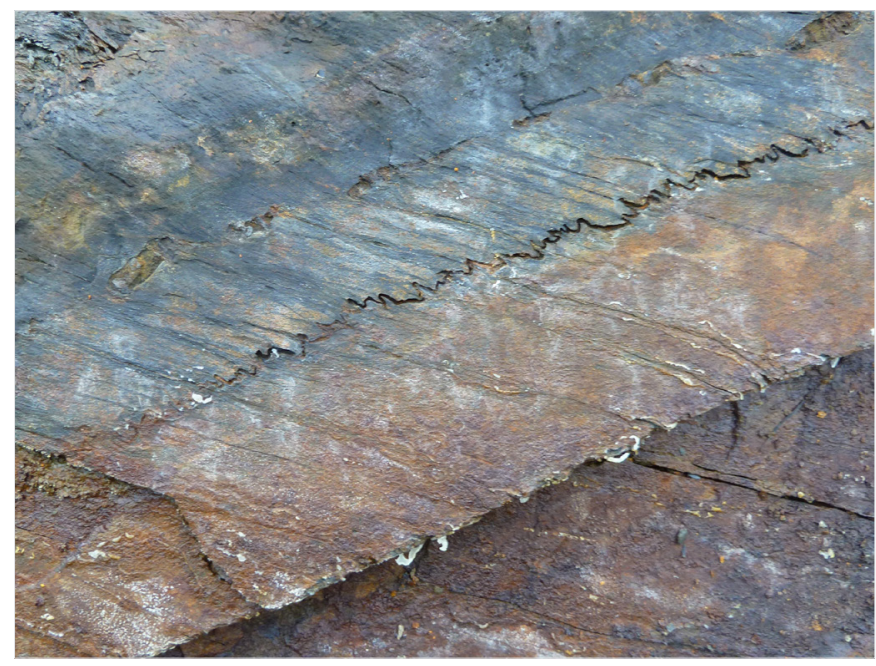

Рис. 8. Осевые поверхности микроскладок, согласные кливажу осевой поверхности (Каменская антиклиналь).

Fig. 8. Axial surfaces of microfolds that are consistent with the cleavage of the axial surface (Kamenskaya anticline).
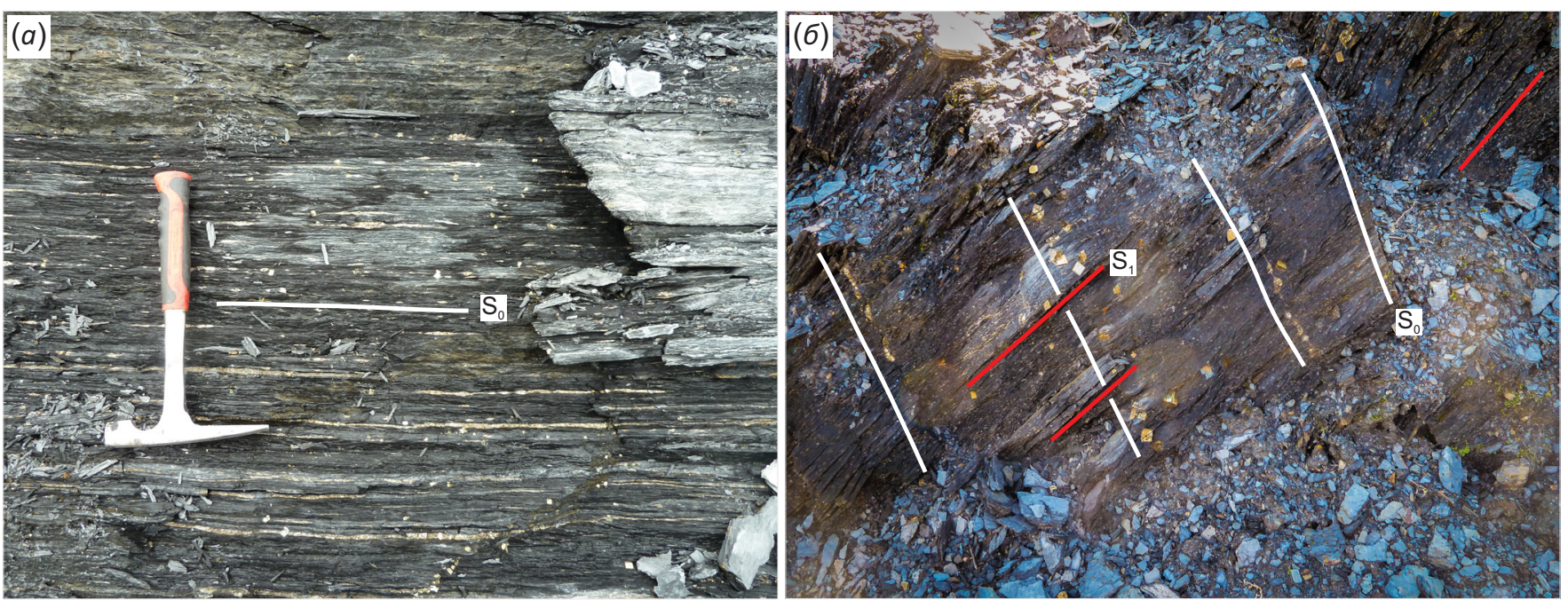

Рис. 9. Фото послойной сульфидной минерализации на месторождении Голец Высочайший.

(a) - ранняя пирит-пирротиновая минерализация; (б) - ранняя пирит-пирротиновая и поздняя пиритовая (кубы) минерализация.

Fig. 9. Layered sulfide mineralization. Photos taken at the Golets Vysochaishy deposit.

(a) - early pyrite-pyrrhotite mineralization; (б) - early pyrite-pyrrhotite and late pyrite (cubes) mineralization. 


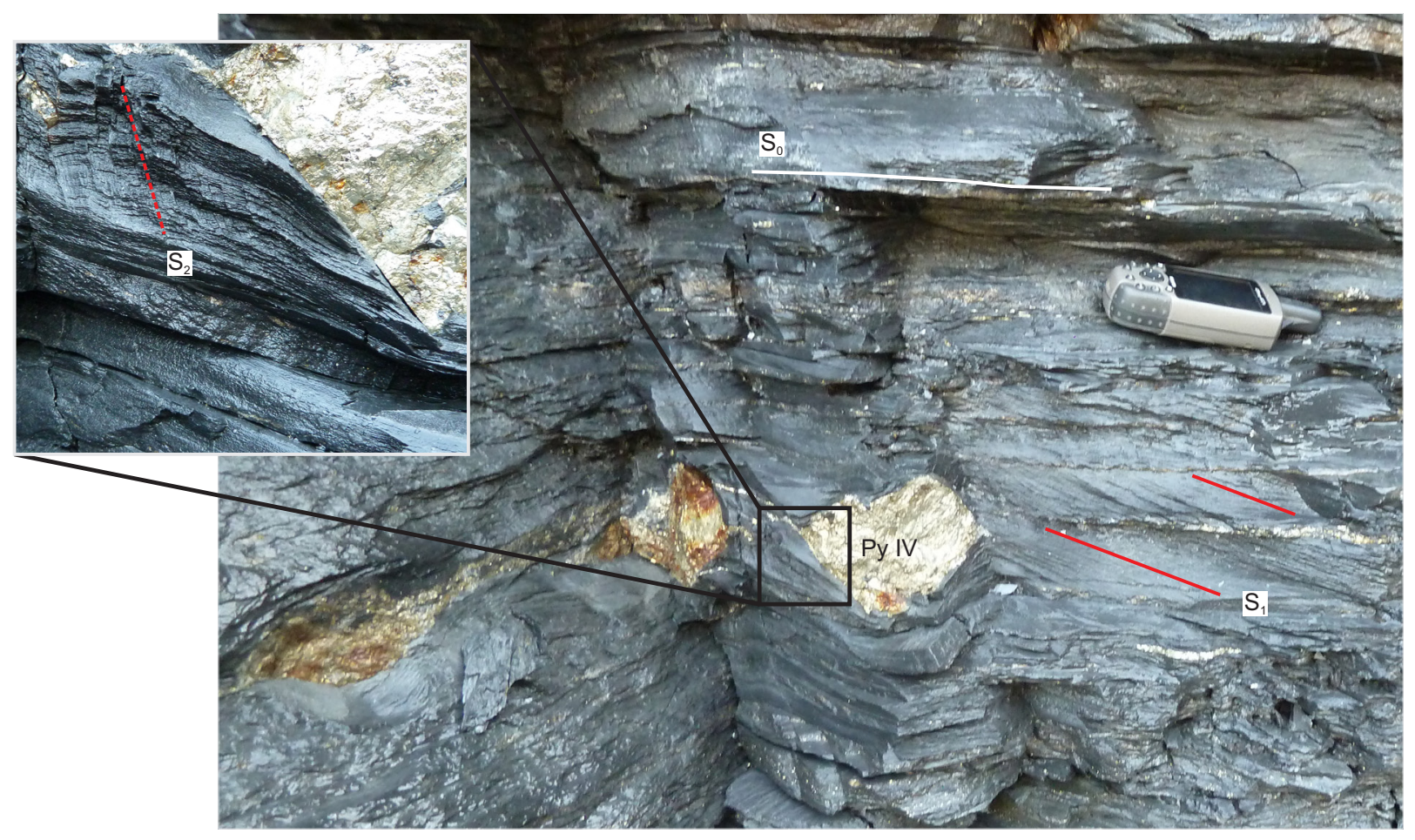

Рис. 10. Деформированный пирит IV в борту карьера в пределах золоторудной зоны. На врезке (увеличенный участок) дискретный кренуляционный кливаж $\mathrm{S}_{2}$.

Fig. 10. Deformed pyrite IV at the quarry side in the gold-ore zone. The inset (zoom-in) shows discrete crenulation cleavage $S_{2}$.

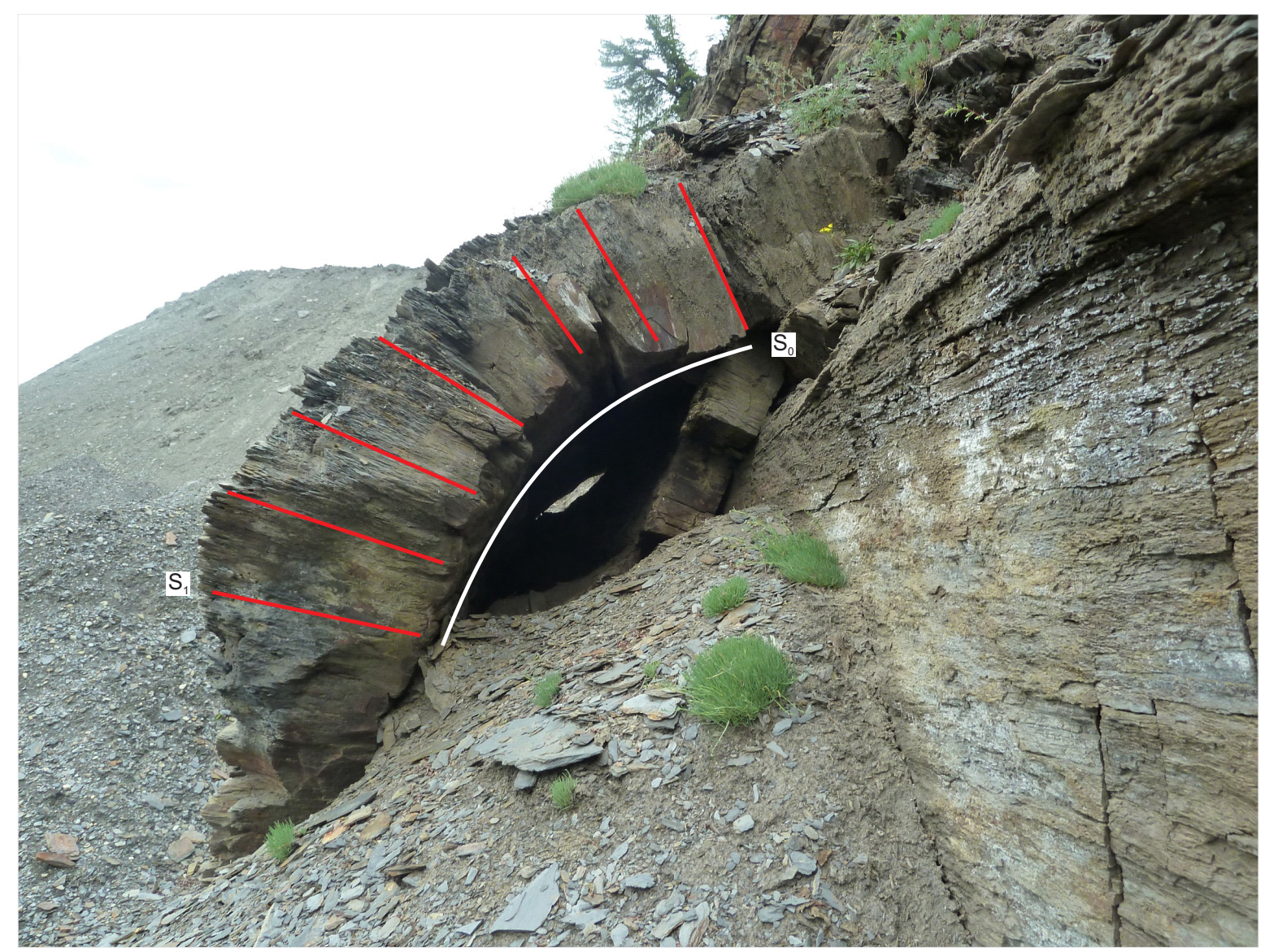

Рис. 11. Веерный кливаж осевой поверхности в замке складки. $S_{0}$ - слоистость, $S_{1}-$ кливаж осевой поверхности.

Fig. 11. Fan cleavage of the axial surface in the fold's hinge. $S_{0}$ - layering, $S_{1}$ - cleavage of the axial surface. 

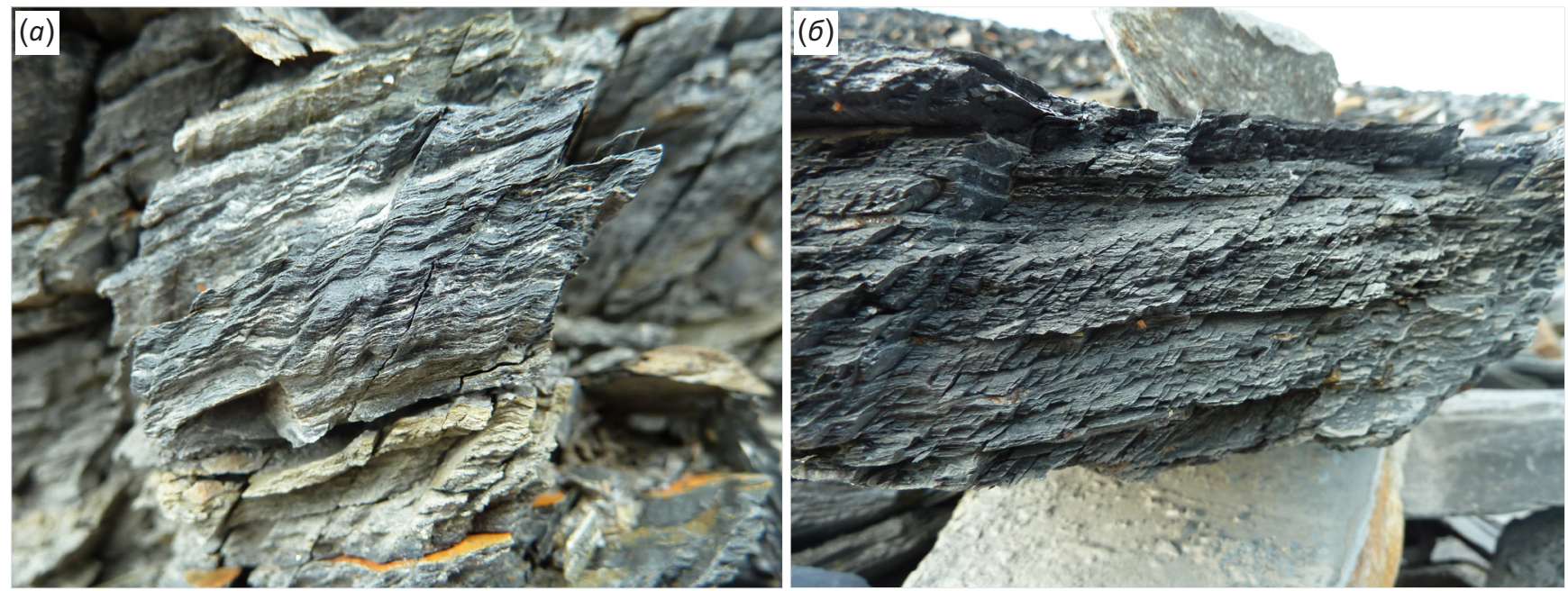

Рис. 12. Фото кренуляционного кливажа $S_{2}$, развитового в рудной зоне с промышленными содержаниями золота.

Fig. 12. Crenulation cleavage $S_{2}$. Photo taken in the ore zone with industrial gold concentrations.
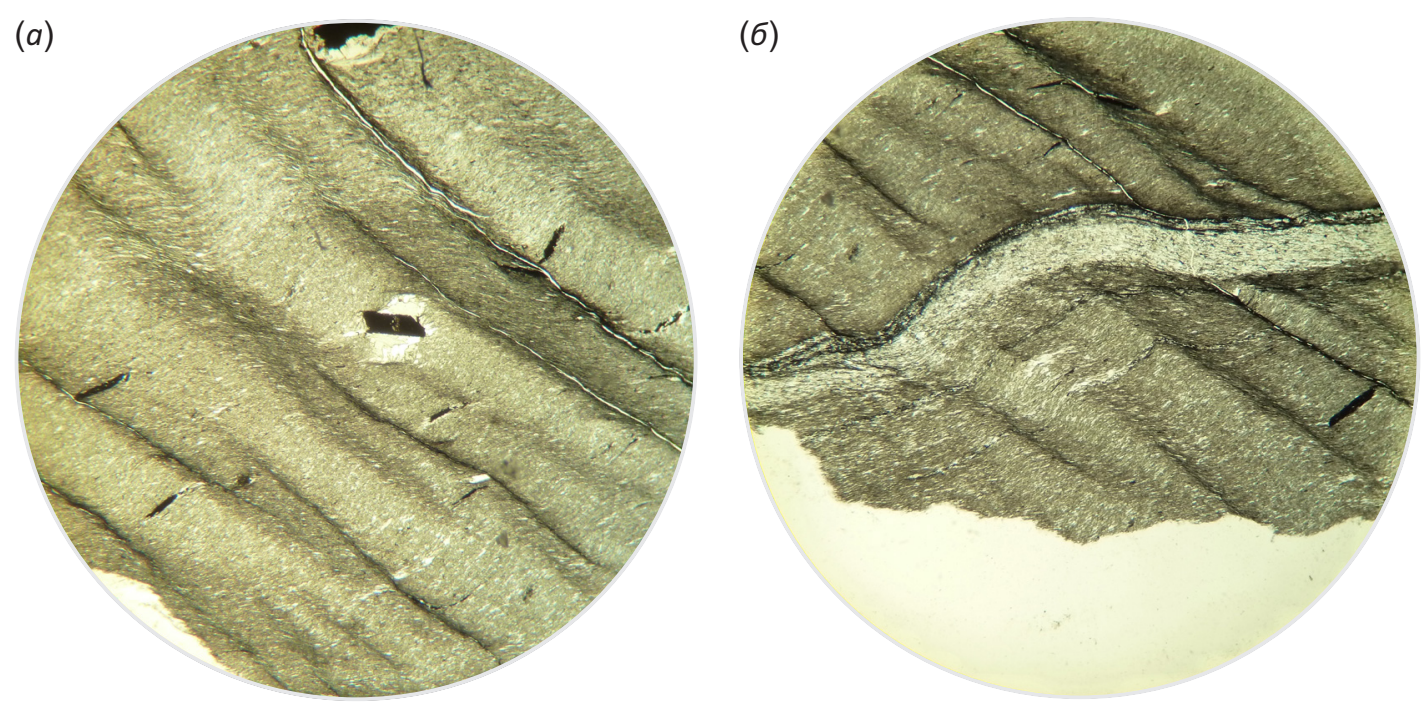

Рис. 13. Фото шлифов кренуляционного кливажа $\mathrm{S}_{2}$. Увеличение $\times 5$.

Fig. 13. Thin sections of crenulation cleavage $S_{2}$. Five-fold zoom-in images.

смяты плоскости ранее образованных кливажа ОП и слоистости.

3. Межслоевые подвижки (срывы), кроме межслоевых складок волочения (см. рис. 5), часто сопровождаются параллельными микротрещинами и микроразломами, секущими плоскости кливажа ОП (см. рис. 7), а также отполированными зеркалами скольжения. Их образование, вероятно, связано с резким снятием напряжений в результате изменения скорости деформации, что приводит к переходу от пластических деформаций к хрупкопластическим.

4. Сформированные крупные кварцевые жилы и прожилки занимают секущее положение по отношению к основным плоскостным структурным элементам.

Важно подчеркнуть, что Каменская антиклиналь и Имняхская синклиналь сформированы в одну деформационную стадию. Каменская антиклиналь имеет тупое восточное окончание, характерное для вырождающихся (затухающих) складок (см. рис. 2). Также на затухание антиклинали в восточной части разреза месторождения указывает пологий угол наклона кливажа ОП и слоистости.

Эта часть разреза характеризуется наличием благоприятных факторов для выявления здесь золоторудных зон, установленных ранее для месторождения Голец Высочайший. К таким факторам относится наличие антиклинальной структуры, отложений черносланцевых пачек хомолхинской свиты и структур кренуляционного кливажа. Данные критерии наличия рудоносных структур были нами зафиксированы в пределах уже известных золоторудных зон, вскрытых в карьере месторождения Голец Высочайший. Таким образом, можно предположить, что эта часть разреза перспективна для выявления здесь золоторудных зон. 


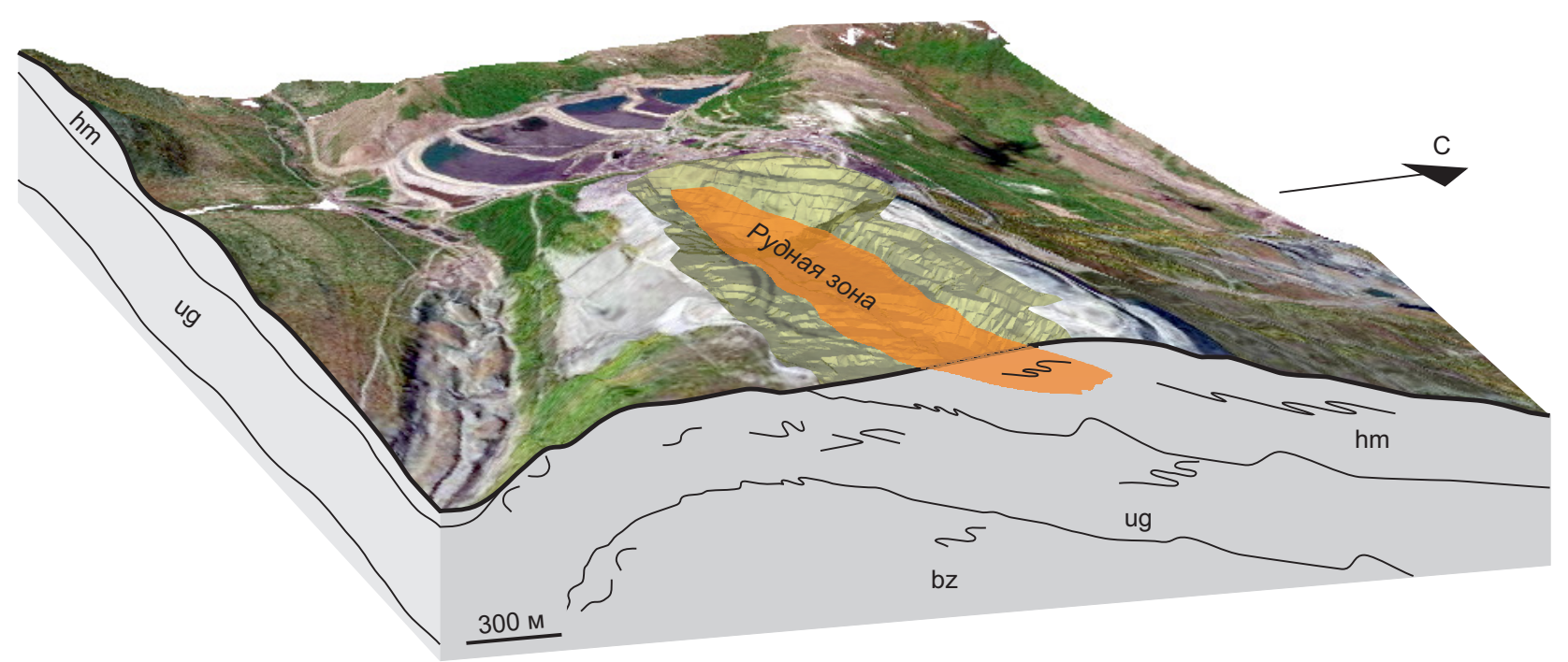

Рис. 14. Объемная схематизированная модель рудовмещающей Каменской антиклинали.

Fig. 14. 3D schematic model of the ore-bearing Kamenskaya anticline.

Главной особенностью месторождения Голец Высочайший является развитие межслоевых зон сульфидизации, в том числе и золотоносной. Неоднократные подвижки приводили к формированию различных генераций пиритов - ранних (жильные) и поздних (крупные кубические формы), приуроченных исключительно к плоскостям слоистости.

Сланцеватость $\mathrm{S}_{1}$ является результатом преобразования более раннего кливажа ОП. По мере нарастания пластических деформаций минералы слюд и кварца в углеродистой толще приобретают направленную ориентировку, в результате чего плоскости кливажа были трансформированы в сланцеватость (см. рис. 7). В работах [Buryak, Khmelevskaya, 1997; Lobanov et al., 1976] эти структуры принимались за разломные зоны, что, по мнению авторов, ошибочно. Установленные в висячем крыле Каменской антиклинали деформации являются результатом межслоевых скольжений. Золоторудная зона приурочена к послойной зоне межслоевого скольжения, в которой возникают структурные элементы, идентичные надвиговым. Однако по геодинамическим признакам это разные структуры: первые располагаются согласно элементам стратификации, а вторые пересекают ее. По всей вероятности, рудообразование происходило в процессе движения растворов в межслоевом пространстве и диффузии полезных компонентов (в том числе и золота) из вмещающих пород под действием тектонических процессов в зоне межслоевых скольжений. К дополнительным факторам перераспределения золота можно относить наложенный кренуляционный кливаж, который обычно возникает в условиях продольного сжатия, формируя серию микроскладочек и плоскостей кливажа. В работе [Tarasova et al., 2020] исследователи пришли к выводу, что при минеральной эволюции золоторудных зон на месторождении Красном происходили процессы декомпрессии с 6 до 0.5 кбар в диапазоне температур $270-380^{\circ} \mathrm{C}$. Этот вывод подразумевает наличие тектонических воздействий при формировании золоторудных зон. По наблюдениям авторов настоящей работы такое воздействие было выражено межслоевыми подвижками с образованием складок волочения. Сброс давлений мог происходить в межслоевых полостях и замках складок. При продольном сжатии на крыльях складок осуществляется растворение вещества под давлением и вынос материала в замковую часть. В этой области создаются условия для формирования микропустот и микротрещин, в которых в связи с возникновением пониженного давления и отлагается растворенный материал, в том числе золото.

На рис. 14 изображена генерализованная объемная модель рудовмещающей Каменской антиклинали. Из рисунка видно, что оруденение располагается в висячем крыле Каменской антиклинали в породах нижней подсвиты хомолхинской свиты, характеризующейся тонким чередованием углеродистых кварц-серицитовых сланцев с известняками, известковистыми сланцами и алевропесчаниками. В замке антиклинали породы хомолхинской свиты эродированы до уровня слабозолотоносных отложений угаханской свиты, где по результатам поисковых работ признаки золотого оруденения не обнаружены. Можно полагать, что эродированная часть Каменской антиклинали являлась одним из источников золота для россыпи в р. Хомолхо.

\section{6. ЗАКЛЮЧЕНИЕ}

Проведенные исследования показали, что структура месторождения была сформирована в два основных этапа: седиментационно-диагенетический и метаморфогенно-деформационный. Первый этап предшествовал основному этапу сжатия. Второй - основной - этап сжатия можно условно разделить на три стадии. На первой стадии ранее накопленная моноклинально залегающая углеродистая толща подверглась продольному 
сжатию юго-юго-западной ориентировки с формированием Имняхской синклинали и Каменской антиклинали. На этой же стадии формировался и кливаж ОП. Продолжающиеся деформационные процессы трансформировали кливаж ОП в сланцеватость и привели к формированию межслоевых складок волочения. Во вторую стадию продолжалась складчато-надвиговая активизация с образованием кренуляционного кливажа в висячем крыле и замке Каменской антиклинали. На третьей стадии происходило внедрение крупных кварцевых жил и прожилков, секущих основные плоскостные структурные элементы. Согласно опубликованным данным [Laverov et al., 2007; Yudovskaya et al., 2011; Nemerov et al., 2010; Chugaev et al., 2014; и др.], между второй ( 450 млн лет) и третьей ( 320 млн лет) стадиями деформаций метаморфогенно-деформационного этапа временной разрыв превышал 100 млн лет.

Исследованиями структурных характеристик месторождения Голец Высочайший главная рудоконтролирующая разломная зона не зафиксирована. Вся потенциально золотоносная сульфидная минерализация приурочена к слоистости. В структурном контроле золотого оруденения, кроме антиклинальной складки, выделена зона межслоевых скольжений. Деформационные стадии формирования структуры месторождения сопровождались межслоевыми подвижками (срывами) с образованием межслоевых складок волочения, субпараллельных трещин и микроразломов. Зону межслоевых скольжений можно рассматривать как благоприятную структурную позицию для мобилизации и переотложения металлов, в том числе золота.

Выделенные структурно-стратиграфические и литологические критерии потенциально рудоносных структур для месторождения Голец Высочайший были установлены в пределах восточной вырождающейся части Каменской антиклинали, в связи с чем ее можно считать перспективной на обнаружение здесь новых золоторудных зон.

\section{7. ЛИТЕРАТУРА/ REFERENCES}

Babyak V.N., Blinov A.V., Tarasova J.I., Budyak A.E., 2019. New Data on the Geological and Structural Features of the Ozhereliye, Ykanskoye, Ugahan and Golets Vysochaishy Gold Fields. Earth Sciences and Subsoil Use 42 (4), 388412 (in Russian) [Бабяк В.Н., Блинов А.В., Тарасова Ю.И., Будяк А.Е. Новые данные о геолого-структурных особенностях золоторудных месторождений Ожерелье, Ыканское, Угахан и Голец Высочайший // Науки о Земле и недропользование. 2019. Т. 42. № 4. С. 388-412]. https:// doi.org/10.21285/2686-9993-2019-42-4-388-412.

Budyak A.E., Goryachev N.A., Skuzovatov S.Y., 2016. Geodynamic Background for Large-Scale Mineralization in the Southern Environs of the Siberian Craton in the Proterozoic. Doklady Earth Sciences 470 (2), 1063-1066. https://doi. org/10.1134/S1028334X1610010X.

Budyak A.E., Skuzovatov S.Y., Tarasova Y.I., Goryachev N.A., Wang K.L., 2019. Common Neoproterozoic - Early Paleozoic Evolution of Ore-Bearing Sedimentary Complexes in the
Southern Siberian Craton. Doklady Earth Sciences 484 (1), 92-96. https: //doi.org/10.1134/S1028334X19010227.

Buryak V.A., 1966. Some Features of Sulphide Type Gold Mineralization in the Lena Region. Russian Geology and Geophysics 8, 34-44 (in Russian) [Буряк B.A. Некоторые особенности золотого оруденения сульфидного типа в Ленском районе // Геология и геофизика. 1966. № 8. C. 34-44].

Buryak V.A., Khmelevskaya N.M., 1997. Sukhoi Log, One of the Largest Gold Deposits in the World: Genesis, Mineralization Distribution Patterns, and Forecasting Criteria. Dal'nauka, Vladivostok, 156p. (in Russian) [Буряк B.A., Хмелевская Н.М. Сухой Лог - одно из крупнейших золоторудных месторождений мира (генезис, закономерности размещения оруденения, критерии прогнозирования). Владивосток: Дальнаука, 1997. 156 с.].

Buryak V.A., Mikhailov B.K., Tsymbalyuk N.V., 2002. Genesis, Distribution Patterns and Prospects of Gold- and Platinum-Bearing Black-Shale Strata. Ores and Metals 6, 25-36 (in Russian) [Буряк В.А., Михайлов Б.К., Цымбалюк Н.В. Генезис, закономерности размещения и перспективы золото- и платиноносности черносланцевых толщ // Руды и металлы. 2002. Т. 6. С. 25-36].

Chugaev A.V., Chernyshev I.V., Shatagin K.N., Oleinikova T.I., Budyak A.E., Tarasova Y.I., Skuzovatov S.Y., 2017. Sources of Clastic Material of the Neoproterozoic Metasedimentary Rocks of the Baikal-Patom Belt, Northern Transbaikalia: Evidence from Sm-Nd Isotope Data. Geochemistry International 55 (1), 60-68. https://doi.org/10.1134/S00 16702916120028.

Chugaev A.V., Plotinskaya O.Y., Chernyshev I.V., Kotov A.A., 2014. Lead Isotope Heterogeneity in Sulfides from Different Assemblages at the Verninskoe Gold Deposit (Baikal-Patom Highland, Russia). Doklady Earth Sciences 457 (1), 887892. https://doi.org/10.7868/S0869565214210191.

Chumakov N.M., Semikhatov M.A., Sergeev V.N., 2013. Vendian Reference Section of Southern Middle Siberia. Stratigraphy and Geological Correlation 21 (4), 359-382. https:// doi.org/10.1134/S0869593813040023.

Distler V.V., Mitrofanov G.L., Nemerov V.K., Kovalenker V.A., Mokhov A.V., Semeikina L.K., Yudovskaya M.A., 1996. Form of Occurrence of Platinum Group Metals and Their Genesis in the Sukhoi Log Gold Ore Deposit, Russia. Geology of Ore Deposits 38 (6), 467-484 (in Russian) [Дистлер В.В., Митрофанов Г.Л., Немеров В.К., Коваленкер В.А., Мохов А.В., Семейкина Л.К., Юдовская М.А. Форма нахождения металлов платиновой группы и их генезис в золоторудном месторождении Сухой Лог (Россия) // Геология рудных месторождений. 1996. Т. 38. № 6. С. 467-484].

Flaass A.S., 1971. Some Features of the Structural Development of the Mama-Bodaibo Series. Geotectonics 6, 58-64 (in Russian) [Флаасс A.C. Некоторые особенности структурного развития Мамско-Бодайбинской серии // Геотектоника. 1971. № 6. С. 58-64].

Goryachev N.A., Ignatiev A.V., Velivetskaya T.A., Budyak A.E., Tarasova Y.I., 2019. Experience in Applying a Local Analysis an Sulfur Isotopes in the Ore Sulfides of the Largest Deposits of Bodaibinsky Synclinoria (Eastern Siberia). Doklady 
Earth Sciences 484 (4), 460-463 (in Russian) [Горячев Н.A., Игнатьев А.В., Веливецкая Т.А., Будяк А.Е., Тарасова Ю.И. Опыт применения локального анализа изотопного состава серы сульфидов руд крупнейших месторождений Бодайбинского синклинория (Восточная Сибирь) // Доклады АН. 2019. Т. 484. № 4. С. 460-463]. https://doi.org/ 10.31857/S0869-56524844460-463.

Ivanov A.I., 2014. Baikal-Patom Gold (Geology, Mineralization, and Prospects). Central Research Institute of Geological Prospecting for Base and Precious Metals, Moscow, 215 p. (in Russian) [Иванов А.И. Золото Байкало-Патома (геология, оруденение, перспективы). М.: ФГУП ЦНИГРИ. 2014. 215 c.].

Kotov A.A., 2013. Structural Features of the Formation of the Verninsky Deposit, Bodaibo Gold-Ore Region. Metallogeny of Ancient and Modern Oceans 1, 205-209 (in Russian) [Котов А.А. Структурные особенности формирования Вернинского месторождения, Бодайбинский золоторудный район // Металлогения древних и современных океанов. 2013. № 1. С. 205-209].

Kucherenko I.V., Gavrilov R.Yu., Martynenko V.G., Verkhozin A.V., 2012. Petrological and Geochemical Features of Ore-Forming Metasomatism in the Verninsky Gold-Ore Deposit, Lena Area. Bulletin of the Tomsk Polytechnic University 321 (1), 22-33 (in Russian) [Кучеренко И.В., Гаврилов Р.Ю., Мартыненко В.Г., Верхозин А.В. Петрологогеохимические черты околорудного метасоматизма в Вернинском золоторудном месторождении (Ленский район) // Известия Томского политехнического университета. 2012. Т. 321. № 1. C. 22-33].

Large R.R., Maslennikov V.V., Robert F., Danyushevsky L.V., Chang Z., 2007. Multistage Sedimentary and Metamorphic Origin of Pyrite and Gold in the Giant Sukhoi Log Deposit, Lena Gold Province, Russia. Economic Geology 102 (7), 12331267. https://doi.org/10.2113/gsecongeo.102.7.1233.

Laverov N.P., Chernyshev I.V., Chugaev A.V., Bairova E.D., Gol'tsman Y.V., Distler V.V., Yudovskaya M.A., 2007. Formation Stages of the Large-Scale Noble Metal Mineralization in the Sukhoi Log Deposit, East Siberia: Results of IsotopeGeochronological Study. Doklady Earth Sciences 415 (1), 810-814. https://doi.org/10.1134/S1028334X07050339.

Lobanov M.P., Radchenko K.M., Chernetskaya I.I., Okhotnikov I.A., Nomokova Yu.A., Novikova E.F., 1976. Ore-Bearing Carbonaceous Pelitoids of Linear Shear Zones of the Patom Upland. Russian Geology and Geophysics 9, 34-45 (in Russian) [Лобанов М.П., Радченко К.М., Чернецкая И.И., Охотников И.А., Номокова Ю.А., Новикова Э.Ф. Рудоносные углистые пелитоиды линейных зон смятия Патомского нагорья // Геология и геофизика. 1976. № 9. C. 34-45].

Meffre S., Large R.R., Scott R.J., Woodhead J., Chang Z., Gilbert S.E., Danyushevsky L.V., Maslennikov V.V., Hergt J.M., 2008. Age and Pyrite Pb-Isotopic Composition of the Giant Sukhoi Log Sediment-Hosted Gold Deposit, Russia. Geochimica et Cosmochimica Acta 72 (9), 2377-2391. https:// doi.org/10.1016/j.gca.2008.03.005.

Nemerov V.K., Stanevich A.M., Razvozzhaeva E.A., Budyak A.E., Kornilova T.A., 2010. Biogenic Sedimentation
Factors of Ore Formation in the Neoproterozoic Strata of the Baikal-Patom Region. Russian Geology and Geophysics 51 (5), 729-747 (in Russian) [Немеров В.К., Станевич А.М., Развозжаева Э.А., Будяк А.Е., Корнилова Т.А. Биогенноседиментационные факторы рудообразования в неопротерозойских толщах Байкало-Патомского региона // Геология и геофизика. 2010. Т. 51. № 5. С. 729-747].

Palenova E.E., Belogub E.V., Novoselov K.A., Maslennikov V.V., Kotlyarov V.A., Blinov I.A., Plotinskaya O.Y., Griboedova I.G., Kuzmenko A.A., 2015. Chemical Evolution of Pyrite at the Kopylovsky and Kavkaz Black Shale-Hosted Gold Deposits, Bodaybo District, Russia: Evidence from Epma and LA-ICP-MS Data. Geology of Ore Deposits 57 (1), 64-84. https://doi.org/10.1134/S107570151501002X.

Powerman V., Shatsillo A., Chumakov N., 2015. Interaction between the Central Asian Orogenic Belt (CAOB) and the Siberian Craton as Recorded by Detrital Zircon Suites from Transbaikalia. Precambrian Research 267 (1), 39-71. https://doi.org/10.1016/j.precamres.2015.05.015.

Sher S.D., 1961. On the Tectonics of the Bodaibo Syncline and the Influence of Some of Its Elements on Gold-Bearing Ore Localization. Proceedings of TsNIGRI 38. P. 30-48 (in Russian) [Шер С.Д. К вопросу о тектонике Бодайбинского синклинорного погружения и влиянии некоторых ее элементов на локализацию золотоносности. Труды ЦНИГРИ. 1961. Вып. 38. С. 30-48].

Tarasova Y.I., Budyak A.E., Chugaev A.V., Goryachev N.A., Tauson V.L., Skuzovatov S.Yu., Reutsky V.N., Abramova V.D., Gareev B.I., Bryukhanova N.N., Parshina A.V., 2020. Mineralogical and Isotope-Geochemical ( $\delta 13 \mathrm{C}, \delta 34 \mathrm{~S}$ and $\mathrm{Pb}-\mathrm{Pb}$ ) Characteristics of the Krasniy Gold Mine (Baikal-Patom Highlands): Constraining Ore-Forming Mechanisms and the Model for Sukhoi Log-Type Deposits. Ore Geology Reviews 119, 103365. https://doi.org/10.1016/j.oregeorev. 2020.103365.

Tarasova Yu.I., Sotskaya O.T., Skuzovatov S.Yu., Vanin V.A., Kulikova Z.I., Budyak A.E., 2016. Mineralogical and Geochemical Evidence for Multi-Stage Formation of the Chertovo Koryto Deposit. Geodynamics \& Tectonophysics 7 (4), 663677 (in Russian) [Тарасова Ю.И., Соцкая О.Т., Скузоватов С.Ю., Ванин В.А., Куликова З.И., Будяк А.Е. Минералого-геохимические свидетельства полистадийности формирования месторождения Чертово Корыто / Г Геодинамика и тектонофизика. 2016. Т. 7. № 4. С. 663-677]. https: //doi.org/10.5800/GT-2016-7-4-0227.

Tauson V.L., Akimov V.V., Lipko S.V., Spiridonov A.M., Budyak A.E., Belozerova O.Yu., Smagunov N.V., 2015. Typomorphism of Pyrite of the Sukhoi Log Deposit (East Siberia). Russian Geology and Geophysics 56 (10), 1773-1796 (in Russian) [Таусон В.Л., Акимов В.В., Липко С.В., Спиридонов А.М., Будяк А.Е., Белозерова О.Ю., Смагунов Н.В. Типоморфизм пирита месторождения Сухой Лог (Восточная Сибирь) // Геология и геофизика. 2015. Т. 56. № 10. C. 1773-1796]. https://doi.org/10.15372/GiG20 151003.

Tauson V.L., Nemerov V.K., Razvozzhaeva E.A., Spiridonov A.M., Lipko S.V., Budyak A.E., 2009. Paragenetic Relations of Pyrite, Carbon and Gold at the Sukhoi Log Deposit, 
and Typomorphism of Pyrite Surface. Doklady Earth Sciences 426 (4), 528-532 (in Russian) [Таусон В.Л., Немеров В.К., Развозжаева Э.А., Спиридонов А.М., Липко С.В., Будяк А.Е. Парагенетические отношения пирита, углерода и золота на месторождении Сухой Лог и типоморфизм поверхности пирита // Доклады АН. 2009. Т. 426. № 4. C. 528-532].

Vanin V.A., Mazukabzov A.M., 2020. Structural Control of Gold Mineralization in the Marakan Ore Node in Northern Transbaikalia (on the Example of the Ozherelye Deposit). Top Problems of Science in the Baikal Region 3, 31-35 (in Russian] [Ванин B.A., Мазукабзов А.М. Структурный контроль золотого оруденения в пределах Мараканского рудного узла в Северном Забайкалье (на примере месторождения Ожерелье) // Актуальные проблемы науки Прибайкалья. 2020. № 3. С. 31-35].
Vood B.L., Popov N.P., 2006. The Giant Gold Deposit Sukhoi Log, Siberia. Russian Geology and Geophysics 47 (3), 315341 (in Russian) [Вуд Б.Л., Попов Н.П. Гигантское месторождение золота Сухой Лог (Сибирь) // Геология и геофизика. 2006. Т. 47. № 3. С. 315-341].

Yudovskaya M.A., Distler V.V., Mokhov A.V., Rodionov N.V., Antonov A.V., Sergeev S.A., 2011. Relationship between Metamorphism and Ore Formation at the Sukhoi Log Gold Deposit Hosted in Black Slates from the Data of U-Th-Pb Isotopic Shrimp-Dating of Accessory Minerals. Geology of Ore Deposits 53 (1), 27-57. https://doi.org/10.1134/S1075701511010077.

Yudovskaya M.A., Distler V.V., Prokof'ev V.Y., Akinfiev N.N., 2016. Gold Mineralization and Orogenic Metamorphism in the Lena Province of Siberia as Assessed from Chertovo Koryto and Sukhoi Log Deposits. Geoscience Frontiers 7 (3), 453-481. https://doi.org/10.1016/j.gsf.2015.07.010. 